\title{
Evaluation of Lychee Fruits and Effect of Osmotic Treatments on Flesh Quality
}

\author{
Eshak M. El-Hadidy \\ Food Technology Research Institute, Agricultural Research Center, Giza, Egypt \\ Email: emgelhadidy1973@gmail.com
}

\begin{abstract}
The lychee (Litchi chinensis Sonn.) fruits (a species of the Sapindaceae family) is of Chinese origin and is perfectly adapted to Egyptian climatic conditions. This study included the evaluation of fresh lychee flesh, seeds and pericarps, also fresh lychee flesh treated with sugar solution (sucrose $20^{\circ} \mathrm{Brix}$ ) in refrigerator $\left(4 \pm 1^{\circ} \mathrm{C}\right)$ during storage for 12 months, also fresh lychee flesh treated with sucrose $40^{\circ}$ Brix (as an osmotic agent) was dehydrated in air oven drier $\left(60^{\circ} \mathrm{C}\right)$ and oven drier under vacuum $\left(50^{\circ} \mathrm{C}\right)$ at ambient temperature $\left(25 \pm 2^{\circ} \mathrm{C}\right)$ during storage for 12 months.

The obtained results showed that, fresh flesh lychee was higher in weight percentage $(73.22 \%)$ than lychee seeds and pericarps (17.58 and $9.20 \%$, respectively) of the total weight of fruits. There were also, no significant variance in crude oil content between fresh flesh lychee and flesh lychee in sugar solution (0.68 and $0.63 \%)$, respectively. While, lychee seeds were possessing high content of crude oil $(3.72 \%)$ followed by lychee flesh dried under vacuum and oven dry (3.62 and $3.53 \%$, respectively) after dipping in sugar agent, then crude oil in pericarps were the lowest content of crude oil $(2.98 \%)$. While, protein and crude fiber contents were higher in pericarps (9.25 and 28.34\%) respectively, than seeds (8.73 and $21.42 \%$ ), also the content of protein and crude fiber were nearly in dried lychee under two treatments of dehydration (6.94, 7.02 and 6.84 and 6.88\%), respectively. Furthermore, dried flesh lychee in oven or under vacuum gave high calories (374.45 and $375.22 \mathrm{kcal} . / 100 \mathrm{~g})$, respectively, followed by lychee seeds then pericarps (317.78 and $287.26 \mathrm{kcal} . / 100 \mathrm{~g})$.

Results, also indicated that, lychee seeds were having the highest contents of $\omega 6$ and $\omega 9$ (2226.65 and $1144.56 \mathrm{mg} / 100 \mathrm{~g}$, on dry weight basis), respectively. While, fresh lychee flesh treated with osmotic solution was decrease in $\omega 9,6$ and 3 contents $(79.25,95.87$ and $29.61 \mathrm{mg} / 100 \mathrm{~g}$, on fresh weight basis, respectively) compared to fresh lychee flesh without any treatment $(98.94,117.16$ and $39.92 \mathrm{mg} / 100 \mathrm{~g}$, on fresh weight basis), respectively. Also, lychee flesh dried under vacuum was higher contents in $\omega 6$ and $\omega 3$ (924.84 and $393.48 \mathrm{mg} / 100 \mathrm{~g}$, on dry weight basis, respectively) than dried by oven dryer, while the same treatment had highest content in $\omega 3$ than other treatment and other parts of lychee fruit (seeds and pericarps).

The results also indicated that, lychee seeds had highest content of total polyphenols, total flavonoids, total carotenoids, L-ascorbic acid and anthocyanins followed by lychee pericarps then fresh lychee flesh except vitamin $\mathrm{C}$, fresh lychee flesh had higher contents then pericarps. These results reflected to antioxidant activity, whereas, seeds had higher antioxidant activity (87.00\%) than fresh lychee flesh and pericarps (81.00 and $78.00 \%)$, respectively.

The results showed that, the total soluble solids, $\mathrm{pH}$ and acidity were ranged from 16.50, 4.42 and 0.38 to $15.95,4.36$ and 0.45 , respectively in fresh osmotic lychee flesh during refrigeration storage. The contents of total polyphenols, total flavonoids and total carotenoids had not significant changes during storage for 12 months. While, vitamin C content was decrease $1.46 \%$ in after storage 12 months, but this decrement is not statistical significance.

The results total polyphenols, total flavonoids, total carotenoids and anthocyanins contents in oven dried $\left(60^{\circ} \mathrm{C}\right)$ on osmotic lychee flesh during storage for 12 months at room temperature $\left(25 \pm 2^{\circ} \mathrm{C}\right)$ had no significantly decrease changes till 8 months. Also, vitamin $\mathrm{C}$ contents in osmotic lychee flesh affected by oven dry treatment till 6 months, in addition, vitamin $\mathrm{C}$ contents was decreased significant till the end of experiment $(7.10 \%)$. While, total polyphenols, carotenoids, anthocyanins contents had no significant decrease till 10 months in dried osmotic lychee flesh at $50^{\circ} \mathrm{C}$ under vacuum (Osmovac) treatment. But, it's observed the content of vitamin $\mathrm{C}$ was gradually significant decreased (from 360.38 to $350.00 \mathrm{mg} / 100 \mathrm{~g}$ on dry weight), the percentage of decrement was $2.88 \%$ at the end of storage in osmovac treatment.
\end{abstract}


The results confirmed that, the fresh lychee flesh treated with osmatic agent and dried lychee flesh at $50^{\circ} \mathrm{C}$ under vacuum (Osmovac) were the most suitable treatments for storing and keeping the antioxidant contents, especially vitamin C. Also, osmovac treatments can retain their high quality of lychee flesh for 1 year at room temperature compared to osmotic oven dried at $60^{\circ} \mathrm{C}$ flesh lychee fruits ( 8 months). While, seeds and pericarps were rich in bioactive components as omega fatty acids, anthocyanins and others, may use in food and pharmaceutical products for their value for sustainable development in future studies.

Keywords: Lychee fruits, Flesh, Seeds, Pericarps, Osmotic agent, Osmotic dehydration, Antioxidants activity, Omega fatty acids, Quality.

\section{Introduction}

Preservation of food to extend its shelf-life, with ensuring its safety and quality, is a central preoccupation of the food industry [1]. Food preservation is the process of treating and handling food to stop or greatly slow down spoilage (loss of quality, edibility or nutritive value) caused or accelerated by microorganism. Preservation usually involves preventing the growth of bacterium, fungus, and other microorganism as well as retarding the oxidation of fat which cause rancidity. It also includes processes to inhibit natural ageing and discoloration that can occur during food preparation such as the enzymatic browning reaction in apples after they are cut. Osmotic dehydration is the phenomenon of removal of water from lower concentration of solute to higher concentration through semi permeable membrane results in the equilibrium condition in both sides of membrane [2]. Yadav and Singh [1] added osmotic dehydration found wide application in the preservation of food-materials since it lowers the water activity of fruits and vegetables. Also, osmotic dehydration is preferred among other methods due to their color, aroma, nutritional constituents and flavor compound retention value.

Lychee (Litchi chinensis Sonn.) is one of the most important fruits, belonging to the family Sapindaceae, and is a delicate fruit commercially valued for its exotic aroma, juicy arils, and nutritional benefits and cultivated in tropical and subtropical countries. The juicy fruit is eaten directly, and juice, vinegar, jelly, yogurt and ice cream are also manufactured from the fruit. It contains $80 \%$ water, $0.4-0.9$ $\mathrm{g} / \mathrm{kg}$ of vitamin C, $0.2-1.1 \%$ acidity, and $11.8-20.6 \%$ total soluble solids [3].

While, the lychee cv. Tailandes showed high pulp yield $(59.0 \%)$, moisture $(80.7 \mathrm{mg} / 100 \mathrm{~g})$ and dietary fiber $(2.2 \mathrm{~g} / 100 \mathrm{~g})$, and a low total energy value $(70.2 \mathrm{kcal} / 100 \mathrm{~g})$. It presented an excellent source of vitamin C $(34.7 \mathrm{mg} / 100 \mathrm{~g})$ [4]. Also, Srivastava et al., [5] added, the fruits contains proteins $(0.83 \mathrm{~g})$, fats $(0.44 \mathrm{~g})$, carbohydrates (sugars $15.23 \mathrm{~g}$ and dietary fiber $1.3 \mathrm{~g}$ ), the fruits are also enriched with vitamin $\mathrm{C}(71.50 \mathrm{mg})$.

Lychee is consumed in fresh or processed forms. Processing and consumption of lychee's fruit lead to generation of by-products such as pericarps and seeds, which are discarded. This leads to their accumulation as waste and subsequently causes environmental pollution [6]. Lychee is about $50 \%$ peel and seed, which are discarded by both industry and consumers. The peel and seed are rich in antioxidants such as ascorbic acid, phenolic compounds including gallic acid, flavonoids (procyanidin B4, procyanidin B2 and epicatechin) and anthocyanins (cyaniding 3-rutinoside, cyanidin-3-glucoside, quercetin3-rutinoside and quercetin 3-glucoside). Pharmacological studies indicate that the by-products of the lychee have various effects including anti-inflammatory, anti-hyperlipidemic, anti-hyperglycemic, hepatic and cardioprotective, as well as having high antioxidant activity [7].

The total phenolic compounds ranged from 0.47 to $1.6 \mathrm{mg} / \mathrm{g}$ fresh weight in the aril of ten different litchi cultivars tested [8]. Flavonoids were the major phenolic compounds in the flesh of litchi with a relative content against total phenolic compounds ranged from 56 to $85 \%$. Total phenolics and total flavonoids in the flesh of litchi increased as fruit developed toward maturity, which were inconsistent with [9], who proposed a loss of soluble tannins and total phenols during fruit develop toward maturity.

Pericarp pigmentation is the result of chlorophyll degradation and anthocyanin accumulation coinciding with the onset of litchi maturation. Anthocyanins and chlorophylls are present mainly in the outer cell layers of the pericarp [3]. For the pericarp of litchi, sound evidences of its health-promoting and medical functions have been obtained via modern phytochemistry and pharmacology studies, and functional compounds have been discovered. Abundant phenolic compounds (51-102 g/kg dry weight) were detected in the pericarp of litchi, and these phenolic compounds exhibited considerably 
bioactivities including high ferric reducing anti-oxidant power (FRAP) and strong activities of 1,1diphenyl-2-picryhydrazyl (DPPH) scavenging, lipid peroxidation inhibiting, and oxidative DNA damage protection [10]. The main phenolics in the pericarp of litchi are condensed tannins, epicatechin, anthocyanidin, anthocyanin, quercetin 3-rutinoside, and quercetin glucoside. In addition, Jiang et al. [11] isolated a novel phenolic, 2-(2-hydroxyl-5-(methoxycarbonyl) phenoxy) benzoic acid, together with kaempferol, isolariciresinol, stigmasterol, butylated hydroxytoluene, 3,4-dihydroxyl benzoate, methyl shikimate, and ethyl shikimate from litchi pericarp methanol extracts.

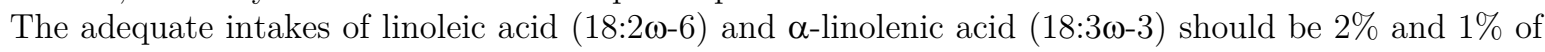
total energy, respectively. Present evidence suggests that $0.2-0.3 \%$ of the energy should be derived from preformed very long-chain $\omega-3$ PUFAs (EPA and DHA) to avoid signs or symptoms of deficiency. This corresponds to approximately $0.5 \mathrm{~g}$ of these -3 fatty acids per day. It should be stressed that this is the minimum intake to avoid clinical symptoms of deficiency. It has been suggested that the ratio between $\omega-3$ and $\omega-6$ fatty acids should be 1:4 as compared to 1:10 in modern dietary habits. Also, Rustan and Drevon [12] recommended daily intake of minimum and maximum $\omega-3$ were 400-600 and 2400$4800 \mathrm{mg} /$ day, respectively and $\omega 6$ were $2400-7200$ and $7200-12000 \mathrm{mg}$ /day, respectively.

Minimum requirements of $\omega 6$ and $\omega 3$ in special formula (infant and young children) according CAC [13] were 300 and $50 \mathrm{mg} / 100 \mathrm{kcal}$. Also, the minimum and maximum ration of $\omega 6: \omega 3$ were 5:1 and 15:1, respectively.

Shelf life of lychee at the ambient temperature $\left(25 \pm 2^{\circ} \mathrm{C}\right)$ is less than $72 \mathrm{~h}$. Postharvest losses are estimated to be $20-30 \%$ of the harvested fruit and could reach as high 50\% [14]. Also, Vacuum drying was a suitable technique for producing shelf-stable lychee fruit with good texture while preserving its desirable original nutrients. Reis et al., [15] added, the consumption of vacuum dried litchi may be beneficial to health due to its remarkable content of phenolic compounds and vitamin C.

There are some major advantages of osmotic dehydration process in the food industry: quality aspect (improvement in terms of color, flavor, texture, product stability and retention of nutrients during storage, energy efficiency, packaging and distribution cost reduction, chemical treatment not required, product stability during storage [16]. They added that, the osmotic dehydration step can be done before, during or after the conventional drying process to shorten the duration of drying time the quality of osmotically dehydrated products is better and shrinkage is considerably lower as compared to products from conventional drying processes.

Therefore, the challenge in this study, aims for prolonging of shelf life of lychee flesh within osmotic treatments either dipping fresh lychee in osmotic agent as sucrose and osmotic dehydration processes, and investigating the changes of bioactive component as affected different preservation treatments.

\section{Materials and Methods}

\subsection{Materials}

Lychee fruits were collected in Pico cultivars Cairo-Alex. Desert road. The selection was based on freshly cut fruit with a uniform size. The pericarp and seeds were removed from the selected flesh fruit.

Flesh lychee was placed in sugar solution (sucrose $20^{\circ}$ Brix), then adding potassium sorbate $0.1 \%$ in solution (w/v).The product was filled into the clean and sterilized glass jar of $450 \mathrm{~g}$ and sealed with crown cork. The filled jar was pasteurized in boiling water bath for $90^{\circ} \mathrm{C} / 30$ sec., then cooled down to $25^{\circ} \mathrm{C}$. The heat treatment was determined based on a research by [17]. The pasteurized was kept for twelve months in glass jar in a refrigerator at $4 \pm 1^{\circ} \mathrm{C}$.

Another treatment, fresh lychee flesh was dipped in osmotic agent (sucrose solution $40{ }^{\circ}$ Brix) $24 \mathrm{~h}$ then sugar solution was removed, after that, lychee flesh drying in oven air drier at $60^{\circ} \mathrm{C}$ and oven under vacuum at $50^{\circ} \mathrm{C}$ till stable dried lychee weight (vacuum osmotic dehydration or osmovac). Then, treatments packing in polyethelene bags for and kept twelve months in ambient temperature $\left(25 \pm 2^{\circ} \mathrm{C}\right)$ under good storage conditions. 


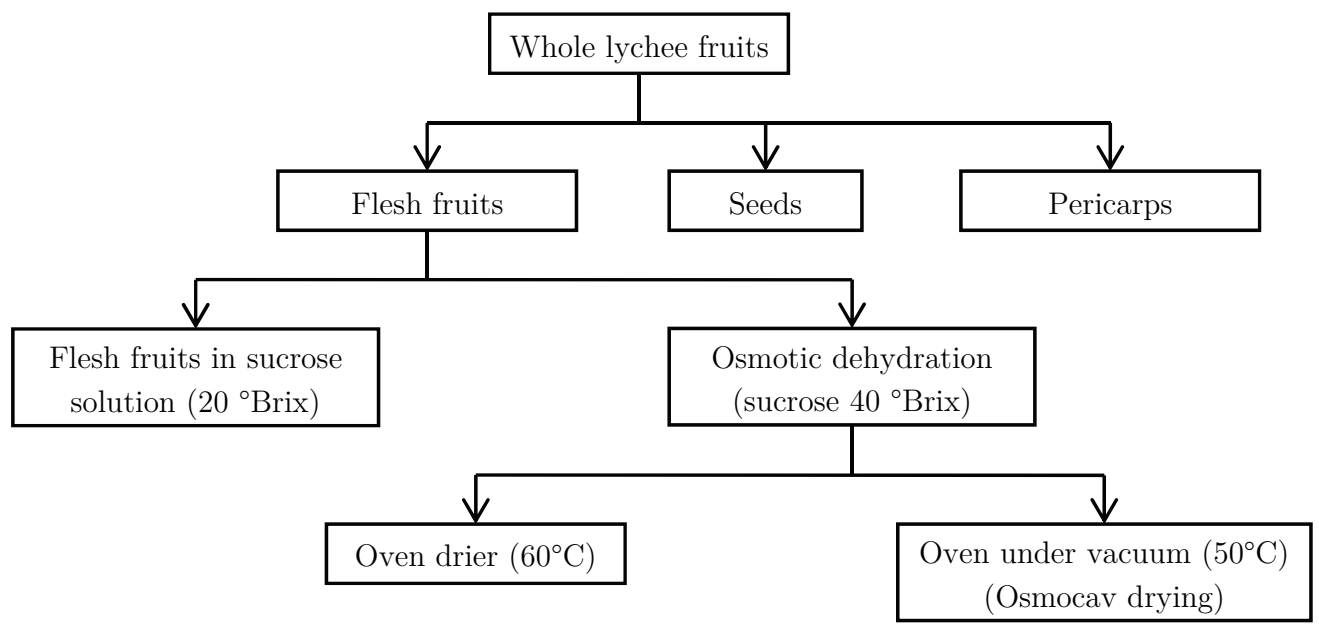

Scheme 1. Flow diagram on osmotic and osmotic dehydration process.

\subsection{Methods}

The chemical analyses such as, moisture, ash, crude oil, crude fiber and crude protein were determined in lychee flesh, pericarps and seeds according the procedures described in [18], while, total carbohydrates were calculated by difference according to [19]. Total calories of fresh flash, fresh flesh dipped in sugar solution and dried in oven and oven under vacuum, seeds and pericarps were calculated by the formula of [20] as follows:

$$
\text { Total calories }=\text { Oil } \times 9+\text { Protein } \times 4+\text { total carbohydrate } \times 4 .
$$

The $\mathrm{pH}$ of fresh lychee flesh and lychee flesh in sugar solution were measured using a $\mathrm{pH}$ meter (HANNA, 8417H, Italy). Acidity was expressed as citric acid percent as mentioned in [18]. The total soluble solids (TSS) value of the lychee products were recorded by using rafractometer has range of 0$100{ }^{\circ}$ Brix (Bellingham-Stanley Lt., England). In each treatment, three readings were taken and their average value was expressed in ${ }^{\circ}$ Brix.

Total polyphenol components were determined using Folin-Ciocalteu method as described by [21]. The content of flavonoids was determined by [22]. Total carotenoids, as $\beta$-carotene, was determination as described by [23], the absorbance was measured at 453, 505, 645 and $663 \mathrm{~nm}$. While, ascorbic acid was analyzed as described by [24].

Total anthocyanin contents in the fruit pericarps were determined by pH-differential method [25] using two buffer systems: potassium chloride buffer $(0.025 \mathrm{M}, \mathrm{pH} 1.0)$ and sodium acetate buffer $(0.4 \mathrm{M}$, $\mathrm{pH}$ 4.5). The extracts were centrifuged at 10,000 rpm for $10 \mathrm{~min}$ and the supernatants were diluted in $\mathrm{pH} 1.0$ and $\mathrm{pH} 4.5$ buffers and absorbance was recorded at 520 and $700 \mathrm{~nm}$ in a spectrophotometer. Finally, the anthocyanin content was calculated in terms of cyanidin-3-glucoside equivalent and expressed as $\mathrm{mg} / \mathrm{g}$ of fresh and dry weight samples.

Omega fatty acids were analyzed as described by [26]. Fatty acid methyl esters (FAME) were prepared from lychee products using a cold saponification method. Lychee products oil (0.25 g) was transferred into a test tube, then added hexane $(5 \mathrm{~mL})$ and methanolic potassium hydroxide $2.0 \mathrm{~N}(0.5$ $\mathrm{mL}$ ). The mixture was centrifuged at $3500 \mathrm{rpm}$ for $2 \mathrm{~min}$. After that, $1 \mu \mathrm{L}$ of upper layer (FSME) was analyzed by an Agilent 6890 series gas liquid chromatography (GLC) equipped with a DB $23(60 \mathrm{~m} \times$ $0.32 \mathrm{~mm} \times 0.251 \mu \mathrm{m}$ capillary column, Agilent Technologies Inc., CA, USA). One micro liter of FAME mixture was injected into GLC system with split/splitless injector and flam ionization detector (FID). The inlet temperature was $250^{\circ} \mathrm{C}$ and the split ratio was 50:1. The constant flow of nitrogen carrier gas was $1.6 \mathrm{~mL} / \mathrm{min}$. The oven temperature was programmed at initial $150^{\circ} \mathrm{C}$, held for $1 \mathrm{~min}$., followed by increase of $10^{\circ} \mathrm{C} / \mathrm{min}$ up to $170^{\circ} \mathrm{C}$, held for $5 \mathrm{~min}$., followed by increase to $220^{\circ} \mathrm{C}$ during $10 \mathrm{~min}$. holding for $3 \mathrm{~min}$. Flame ionization detector was set at $270^{\circ} \mathrm{C}$ with $450 \mathrm{~mL} / \mathrm{min}$ air flow, $40 \mathrm{~mL}$ hydrogen flow and $25 \mathrm{~mL}$ nitrogen flow. 
The free radical scavenging activity of the extracts was examined using DPPH radical according to the method of [27] with slight modification. $1.0 \mathrm{ml}$ of various concentrations of ethanolic extracts $(2-10$ $\mathrm{mg} / \mathrm{ml}$ ) was mixed with $1.0 \mathrm{ml}$ of $0.8 \mathrm{mM}$ DPPH solution. The mixture was shaken vigorously and left to stand for $30 \mathrm{~min}$ and the absorbance was measured at $517 \mathrm{~nm}$ against a reagent blank. L-ascorbic acid was used as standards. The inhibition percentage for scavenging DPPH radical was calculated according to the equation:

$$
\text { Decolorization } \%=(1-\mathrm{ABS} \text { sample/ABS control }) \times 100 \% \text {. }
$$

\subsection{Statistical Analysis}

All analyses were performed using three replications. The obtained data from each treatment in respect to different parameters during storage were subjected to analysis of variance (ANOVA), with treatment and storage time as sources of variation. Tukey's HSD (Honestly significant difference) test was carried out at a significance level of $\mathrm{P} \leqslant 0.05$ to ascertain significant differences between the means. All analyses were performed using the SPSS software package (Version 19.0 for Windows 2000; SPSS Inc., Chicago, IL, USA) [28].

\section{Results and Discussions}

Fresh flesh lychee had higher weight percentage (73.22\%) than lychee seeds and pericarps (17.58 and $9.20 \%$ ), respectively. While, [5] found fruits containing $60 \%$ juice, $8 \%$ rag, $19 \%$ seed and $13 \%$ skin on the basis of variety and climate.

Table 1. Weight means of fresh flesh, seeds and pericarps lychee (g/100g fresh weight).

\begin{tabular}{ccc}
\hline Fresh flesh & Seeds & Pericarps \\
\hline $73.22 \pm 4.25$ & $17.58 \pm 2.60$ & $9.20 \pm 1.97$ \\
\hline
\end{tabular}

Means of 16 fruit \pm SD

Table 2. Macrocomponents in fresh and osmotic dehydration flesh, seeds and pericarps lychee $(\mathrm{g} / 100 \mathrm{~g}$ on dry weight basis).

\begin{tabular}{ccccccc}
\hline \multirow{2}{*}{ Constituents } & \multirow{2}{*}{$\begin{array}{c}\text { Fresh } \\
\text { Flesh* }^{*}\end{array}$} & $\begin{array}{c}\text { Flesh in } \\
\text { sucrose } \\
\text { solution** }\end{array}$ & Oven air & $\begin{array}{c}\text { Osmotic dehydration } \\
\text { Under }\end{array}$ & Seeds & Pericarps \\
& & & & & & \\
\hline Crude Oil & $0.68^{\mathrm{c}} \pm 0.09$ & $0.63^{\mathrm{c}} \pm 0.04$ & $3.53^{\mathrm{ab}} \pm 0.23$ & $3.62^{\mathrm{ab}} \pm 0.35$ & $4.56^{\mathrm{a}} \pm 0.87$ & $2.98^{\mathrm{b}} \pm 0.48$ \\
Crude protein & $0.92^{\mathrm{c}} \pm 0.10$ & $0.91^{\mathrm{c}} \pm 0.09$ & $6.95^{\mathrm{b}} \pm 1.23$ & $7.02^{\mathrm{b}} \pm 1.11$ & $8.73^{\mathrm{ab}} \pm 0.99$ & $9.25^{\mathrm{a}} \pm 1.00$ \\
crude fiber & $1.29^{\mathrm{d}} \pm 0.32$ & $1.27^{\mathrm{d}} \pm 0.29$ & $6.84^{\mathrm{c}} \pm 1.45$ & $6.88^{\mathrm{c}} \pm 1.89$ & $21.42^{\mathrm{b}} \pm 2.38$ & $28.34^{\mathrm{a}} \pm 3.68$ \\
Total carbohydrates & $15.94^{\mathrm{d}} \pm 1.28$ & $15.88^{\mathrm{d}} \pm 1.31$ & $85.56^{\mathrm{a}} \pm 4.85$ & $85.52^{\mathrm{a}} \pm 5.80$ & $81.85^{\mathrm{c}} \pm 6.32$ & $84.20^{\mathrm{ab}} \pm 4.90$ \\
Ash & $0.52^{\mathrm{c}} \pm 0.06$ & $0.54^{\mathrm{c}} \pm 0.08$ & $3.80^{\mathrm{b}} \pm 0.92$ & $3.84^{\mathrm{b}} \pm 0.74$ & $4.86^{\mathrm{a}} \pm 0.88$ & $3.57^{\mathrm{b}} \pm 0.63$ \\
Energy /kcal. & $68.40^{\mathrm{d}} \pm 4.34$ & $67.75^{\mathrm{d}} \pm 5.60$ & $374.45^{\mathrm{a}} \pm 12.37$ & $375.22^{\mathrm{a}} \pm 11.08$ & $317.68^{\mathrm{b}} \pm 9.56$ & $287.26^{\mathrm{c}} \pm 7.3$ \\
\hline
\end{tabular}

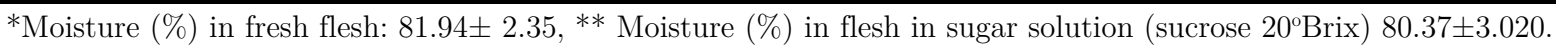

Means having the same letter within row are not significantly different at $\mathrm{p}<0.05$. Data were means \pm SD.

Results in table (2) showed that no significant variance in crude oil content between fresh flesh lychee and flesh lychee dipped in sugar solution (0.68 and $0.63 \%)$, respectively. In the same table, lychee seeds had highest content of crude oil (3.72\%) followed by lychee dried under vacuum and oven dry (3.62 and $3.53 \%)$, respectively, while crude oil in pericarps were the lowest content of crude oil (2.98\%).Moreover, protein and crude fiber contents had higher in pericarps (9.25 and 28.34\%) respectively, than seeds (8.73 and $21.42 \%$, while the contents of protein and crude fiber had nearly in dried lychee under two type of dehydration $(6.94,7.02$ and 6.84 and $6.88 \%)$, respectively. Furthermore, total carbohydrate was ranged from 81.85 to $85.56 \%$ and ash content was ranged from 3.57 to $4.86 \%$ in lychee dried, seeds and 
pericarps. On the other view, dried lychee in oven or under vacuum gave high calories (374.45 and $375.22 \mathrm{kcal}$.$) , respectively, followed by lychee seeds then pericarps (317.78 and 287.26 \mathrm{kcal}$.$) .$

Obtained results cleared that, there is no significant variance in chemical contents and total calories between fresh lychee and flesh lychee dipped in sugar solution, also the same observation in two dehydration technique in fresh lychee after treated with sugar solution.

Table 3. Omega fatty acids contents $(\mathrm{mg} / 100 \mathrm{~g})$ in fresh, flesh treated with osmotic agent, flesh osmotic dehydration treatments, seeds and pericarps lychee fruits.

\begin{tabular}{|c|c|c|c|c|c|c|}
\hline \multirow[b]{2}{*}{ Constituents } & \multirow[b]{2}{*}{$\begin{array}{c}\text { Fresh } \\
\text { lychee flesh }\end{array}$} & \multirow{2}{*}{$\begin{array}{c}\text { Fresh lychee } \\
\text { flesh in } \\
\text { osmotic } \\
\text { solution }\end{array}$} & \multicolumn{2}{|c|}{ Osmotic dehydration } & \multirow[b]{2}{*}{ Dried Seeds } & \multirow[b]{2}{*}{$\begin{array}{c}\text { Dried } \\
\text { Pericarps }\end{array}$} \\
\hline & & & $\begin{array}{c}\text { Flesh Dried } \\
\text { treated by } \\
\text { Oven air }\end{array}$ & $\begin{array}{c}\text { Flesh Dried } \\
\text { Under } \\
\text { vacuum } \\
\end{array}$ & & \\
\hline Crude oil \% & 0.68 & 0.63 & 3.53 & 3.62 & 4.56 & 2.98 \\
\hline$m g / 100 g$ & 680.00 & 630.00 & 3530.00 & 3600.00 & 4560.00 & 2980.00 \\
\hline $\mathrm{C} 18: 1 \omega 9$ & 14.55 & 12.58 & 6.44 & 7.42 & 25.10 & 11.78 \\
\hline$m g / 100 g$ & 98.94 & 79.25 & 227.33 & 267.12 & 1144.56 & 351.04 \\
\hline $\mathrm{C} 18: 2 \omega 6$ & 13.37 & 11.61 & 3.42 & 3.70 & 8.40 & 8.04 \\
\hline $\mathrm{C} 18: 3 \omega 6$ & 3.86 & 3.61 & 21.35 & 21.99 & 40.43 & 0.00 \\
\hline Total $\omega 6$ & 17.23 & 15.22 & 24.70 & 25.69 & 48.83 & 8.04 \\
\hline$m g / 100 g$ & 117.16 & 95.87 & 871.91 & 924.84 & 2226.65 & 238.40 \\
\hline $\mathrm{C} 18: 3 \omega 3$ & 5.87 & 4.70 & 0.00 & 10.93 & 3.75 & 6.35 \\
\hline $\mathrm{mg} / 100 \mathrm{~g}$ & 39.92 & 29.61 & 0.00 & 393.48 & 171.00 & 189.23 \\
\hline$\omega 3: \omega 6$ ratio & 2.93 & 3.24 & 0.00 & 2.35 & 13.02 & 1.26 \\
\hline
\end{tabular}

The lychee treated with sugar solution $\left(20^{\circ}\right.$ Brix) decreased in $\omega 9,6$ and 3 contents $(79.25,95.87$ and $29.61 \mathrm{mg} / 100 \mathrm{~g})$, respectively compared to fresh lychee flesh (98.94, 117.16 and $39.92 \mathrm{mg} / 100 \mathrm{~g})$, respectively (Table 3). Also, lychee seeds was the highest content of $\omega 6$ and $\omega 9$ (2226.65 and 1144.56 $\mathrm{mg} / 100 \mathrm{~g})$, respectively. While, lychee flesh dried under vacuum was higher contents in $\omega 6$ and $\omega 3$ (924.84 and $393.48 \mathrm{mg} / 100 \mathrm{~g}$ ), respectively than dried by oven dryer, while the same treatment was highest content in $\omega 3$ than other treatment and other parts of lychee fruit. Furthermore, It's observed that, the $\omega 3$ was absent in dried lychee by oven dryer, may the air in oven dry broken and degraded the content of $\omega 3$ by oxidation.

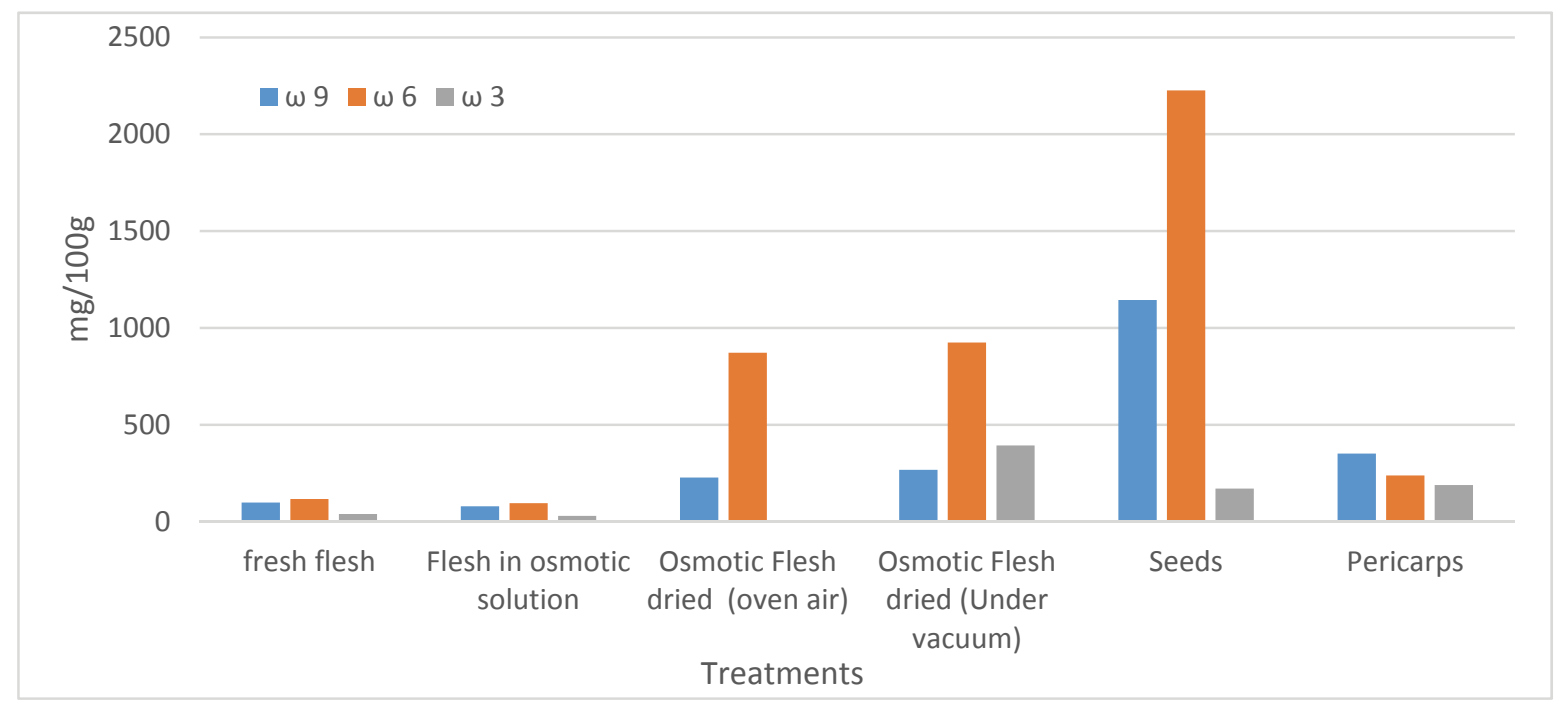

Figure 1. Omega fatty acids contents $(\mathrm{mg} / 100 \mathrm{~g})$ in fresh, flesh treated with osmotic agent, flesh osmotic dehydration treatments, seeds and pericarps lychee fruits. 
According to [12 and 13] who suggested that the ratio between $\omega-3$ and $\omega-6$ fatty acids should be 1:4 as compared to 1:10 in modern dietary habits, $100 \mathrm{~g}$ of fresh flesh lychee, flesh lychee in sugar solution covered 2.93 and 3.23 ratio. Also, it's observed that lychee seeds was higher ratio (13.02) than other treatments. On the other view, drying under vacuum was better than dried with oven air dried treatments, the dried in oven air dryer was lost $\omega 3$ contents, it's reflected to $\omega 3$ : $\omega 6$ ratio.

Table 4. Bioactive components in lychee flesh, seeds and pericarps (on fresh weight basis mg/100g)

\begin{tabular}{cccc}
\hline Constituents & Fresh flesh $^{*}$ & Seeds & Pericarps \\
\hline Total polyphenols & $19.23^{\mathrm{c}} \pm 1.93$ & $71.64^{\mathrm{a}} \pm 4.20$ & $53.38^{\mathrm{b}} \pm 3.88$ \\
Total flavonoids & $2.91^{\mathrm{c}} \pm 0.38$ & $34.72^{\mathrm{a}} \pm 2.24$ & $18.22^{\mathrm{b}} \pm 1.84$ \\
Total carotenoids & $36.24^{\mathrm{c}} \pm 3.00$ & $195.09^{\mathrm{a}} \pm 1.53$ & $120.73^{\mathrm{b}} \pm 8.40$ \\
L-Ascorbic acid & $45.32^{\mathrm{b}} \pm 3.53$ & $75.78^{\mathrm{a}} \pm 4.02$ & $22.69^{\mathrm{c}} \pm 1.23$ \\
Anthocyanins (mg/g) & $1.82^{\mathrm{c}} \pm 0.25$ & $35.24^{\mathrm{a}} \pm 2.13$ & $19.92^{\mathrm{b}} \pm 1.84$ \\
Antioxidant activity DPPH (\%) & $81.00^{\mathrm{b}} \pm 2.10$ & $87.00^{\mathrm{a}} \pm 4.12$ & $78.00^{\mathrm{ab}} \pm 6.24$ \\
\hline
\end{tabular}

Means having the same letter within row are not significantly different at $\mathrm{p}<0.05$. Data were means $\pm \mathrm{SD}$

The contents of antioxidants are shown in table (4). Results indicated that lychee seeds had the highest content of total polyphenols, total flavonoids, total carotenoids, L-ascorbic acid and anthocyanins followed by lychee pericarps then fresh flesh except vitamin $\mathrm{C}$, lychee fresh flesh was higher contents then pericarps. These results reflected to antioxidant activity, it's concluded that seeds were higher antioxidant activity (87.00\%) than fresh flesh and pericarps (81.00 and $78.00 \%)$, respectively.

L-Ascorbic acid is found to be the major components in the aril of lychee, which ranges from 0.1 to $0.4 \mathrm{mg} / \mathrm{g}$ fresh weight at maturity depended on cultivars [8]. While, $6.5-10 \mathrm{mg} /$ day vitamin $\mathrm{C}$ will prevent the appearance of survey. Also, FAO/WHO report [29] indicated, the recommended nutrient intakes (RNIs) for vitamin $\mathrm{C}$ in infant and children was $25-35 \mathrm{mg} /$ day, adults $45 \mathrm{mg} /$ day, pregnancy 55 $\mathrm{mg} /$ day and lactation was $70 \mathrm{mg} /$ day. On the other view, minimum requirement of L-ascorbic acid 10 $\mathrm{mg} / 100 \mathrm{kcal}$ in special dietary use (infant and young children) according to CAC [13]. In these reports, these results indicated that the lychee flesh, seeds or pericarps were rich in vitamin $\mathrm{C}$ and may covered RNI in different human age stages.

Table 5. Physicochemical analyses in fresh lychee flesh during storage for 12 months dipping in sugar solution $\left(60^{\circ}\right.$ Brix $)$.

\begin{tabular}{ccccc}
\hline \multirow{2}{*}{ Constituents } & \multicolumn{2}{c}{ TSS $\left({ }^{\circ}\right.$ Brix $)$} & \multicolumn{2}{c}{ pH } \\
& Flesh & Sugar solution & Flesh & Sugar solution \\
\hline Zero time & $16.50^{\mathrm{a}} \pm 1.03$ & $16.02^{\mathrm{a}} \pm 0.85$ & $4.42^{\mathrm{a}} \pm 0.03$ & $4.41^{\mathrm{a}} \pm 0.03$ \\
2 months & $16.50^{\mathrm{a}} \pm 0.99$ & $16.00^{\mathrm{a}} \pm 0.94$ & $4.40^{\mathrm{a}} \pm 0.05$ & $4.40^{\mathrm{a}} \pm 0.03$ \\
$\mathbf{4}$ months & $16.32^{\mathrm{a}} \pm 1.40$ & $15.90^{\mathrm{a}} \pm 1.31$ & $4.39^{\mathrm{a}} \pm 0.03$ & $4.39^{\mathrm{a}} \pm 0.03$ \\
$\mathbf{6}$ months & $16.20^{\mathrm{a}} \pm 1.22$ & $15.88^{\mathrm{a}} \pm 1.12$ & $4.38^{\mathrm{a}} \pm 0.03$ & $4.39^{\mathrm{a}} \pm 0.04$ \\
$\mathbf{8}$ months & $16.18^{\mathrm{a}} \pm 1.13$ & $15.88^{\mathrm{a}} \pm 1.29$ & $4.37^{\mathrm{a}} \pm 0.05$ & $4.38^{\mathrm{a}} \pm 0.04$ \\
$\mathbf{1 0}$ months & $15.98^{\mathrm{a}} \pm 1.05$ & $15.75^{\mathrm{a}} \pm 1.00$ & $4.37^{\mathrm{a}} \pm 0.04$ & $4.38^{\mathrm{a}} \pm 0.05$ \\
$\mathbf{1 2}$ months & $15.95^{\mathrm{a}} \pm 1.14$ & $15.74^{\mathrm{a}} \pm 1.27$ & $4.36^{\mathrm{a}} \pm 0.06$ & $4.37^{\mathrm{a}} \pm 0.06$ \\
\hline
\end{tabular}

Means having the same letter within row are not significantly different at $\mathrm{p}<0.05$. Data were means $\pm \mathrm{SD}$.

Total soluble solids (TSS) in lychee flesh fruit and their dipping sugar solution ranged from 16.50 to $15.74^{\circ}$ Brix (table 5). Results observed that slightly decreased in TSS during storage for 12 months but not significant, also ${ }^{\circ}$ Brix degree equal approximately in Flesh fruits and in sugar solution. The same indication in $\mathrm{pH}$ value, the $\mathrm{pH}$ was gradually decrement but not significant in lychee flesh and its dipping sugar solution (ranged from 4.42 and 4.36) during storage for 12 months. These TSS and pH balance between lychee fruits and its sugar solution may cause elongation of shelf life. 
Table 6. Quality parameters and antioxidant contents in fresh lychee flesh fruit during storage for 12 months in sucrose solution $\left(20^{\circ}\right.$ Brix) in refrigerator at $4 \pm 1^{\circ} \mathrm{C}$.

\begin{tabular}{cccccccc}
\hline Constituents & 0-time & $\mathbf{2}$ months & $\mathbf{4}$ months & $\mathbf{6}$ months & $\mathbf{8}$ months & 10months & 12 months \\
\hline TSS ( ${ }^{\circ}$ Brix) & $16.50^{\mathrm{a}}$ & $16.50^{\mathrm{a}}$ & $16.32^{\mathrm{a}}$ & $16.20^{\mathrm{a}}$ & $16.18^{\mathrm{a}}$ & $15.98^{\mathrm{a}}$ & $15.95^{\mathrm{a}}$ \\
& \pm 1.03 & \pm 0.99 & \pm 1.40 & \pm 1.22 & \pm 1.13 & \pm 1.05 & \pm 1.14 \\
pH & $4.42^{\mathrm{a}}$ & $4.40^{\mathrm{a}}$ & $4.39^{\mathrm{a}}$ & $4.38^{\mathrm{a}}$ & $4.37^{\mathrm{a}}$ & $4.37^{\mathrm{a}}$ & $4.36^{\mathrm{a}}$ \\
& \pm 0.03 & \pm 0.05 & \pm 0.03 & \pm 0.03 & \pm 0.05 & \pm 0.04 & \pm 0.06 \\
Acidity \% & $0.38^{\mathrm{a}}$ & $0.39^{\mathrm{a}}$ & $0.39^{\mathrm{a}}$ & $0.41^{\mathrm{a}}$ & $0.43^{\mathrm{a}}$ & $0.45^{\mathrm{a}}$ & $0.45^{\mathrm{a}}$ \\
(as citric acid) & \pm 0.09 & \pm 0.08 & \pm 0.07 & \pm 0.05 & \pm 0.03 & \pm 0.02 & \pm 0.03 \\
Total polyphenols & $19.23^{\mathrm{a}}$ & $19.22^{\mathrm{a}}$ & $19.22^{\mathrm{a}}$ & $19.20^{\mathrm{a}}$ & $19.20^{\mathrm{a}}$ & $19.18^{\mathrm{a}}$ & $19.18^{\mathrm{a}}$ \\
$\quad$ (mg/100g) & \pm 1.35 & \pm 1.44 & \pm 1.40 & \pm 1.25 & \pm 1.37 & \pm 1.52 & \pm 1.48 \\
Toal flavonoids & $2.91^{\mathrm{a}}$ & $2.91^{\mathrm{a}}$ & $2.90^{\mathrm{a}}$ & $2.88^{\mathrm{a}}$ & $2.85^{\mathrm{a}}$ & $2.83^{\mathrm{a}}$ & $2.83^{\mathrm{a}}$ \\
(mg/100g) & \pm 0.13 & \pm 0.19 & \pm 0.24 & \pm 0.20 & \pm 0.23 & \pm 0.28 & \pm 0.25 \\
Total carotenoids & $36.24^{\mathrm{a}}$ & $36.20^{\mathrm{a}}$ & $36.18^{\mathrm{a}}$ & $36.15^{\mathrm{a}}$ & $36.12^{\mathrm{a}}$ & $36.10^{\mathrm{a}}$ & $36.09^{\mathrm{a}}$ \\
(mg/100g) & \pm 3.80 & \pm 3.73 & \pm 3.22 & \pm 3.26 & \pm 3.85 & \pm 4.02 & \pm 3.45 \\
L-Ascorbic acid & $36.24^{\mathrm{a}}$ & $45.16^{\mathrm{a}}$ & $45.10^{\mathrm{a}}$ & $44.92^{\mathrm{a}}$ & $44.82^{\mathrm{a}}$ & $44.68^{\mathrm{a}}$ & $44.58^{\mathrm{a}}$ \\
(Vitamin-C mg/100g) & \pm 3.52 & \pm 3.74 & \pm 4.10 & \pm 3.83 & \pm 4.02 & \pm 3.79 & \pm 3.89 \\
Anthocyanins & $1.82^{\mathrm{a}}$ & $1.80^{\mathrm{a}}$ & $1.80^{\mathrm{a}}$ & $1.76^{\mathrm{a}}$ & $1.75^{\mathrm{a}}$ & $1.71^{\mathrm{a}}$ & $1.68^{\mathrm{a}}$ \\
$\quad$ (mg/g) & \pm 0.13 & \pm 0.19 & \pm 0.17 & \pm 0.19 & \pm 0.21 & \pm 0.22 & \pm 0.25 \\
Antioxidant activity & $81.76^{\mathrm{a}}$ & $81.00^{\mathrm{a}}$ & $80.65^{\mathrm{a}}$ & $80.12^{\mathrm{a}}$ & $79.70^{\mathrm{a}}$ & $78.90^{\mathrm{a}}$ & $78.10^{\mathrm{a}}$ \\
DPPH (\%) & \pm 2.30 & \pm 2.82 & \pm 3.21 & \pm 3.00 & \pm 3.30 & \pm 3.27 & \pm 3.88 \\
\hline
\end{tabular}

Means having the same letter within row are not significantly different at $\mathrm{p}<0.05$. Data were means \pm SD.

Table 7. Effect of oven dried at $60^{\circ} \mathrm{C}$ on osmotic lychee flesh (sucrose $40^{\circ} \mathrm{Brix}$ ) antioxidants contents during storage for 12 months at ambient temperature $\left(25 \pm 2^{\circ} \mathrm{C}\right)$.

\begin{tabular}{|c|c|c|c|c|c|c|c|}
\hline Constituents & 0-time & 2 months & 4 months & 6 months & 8 months & 10 months & 12 months \\
\hline Total polyphenols & $99.43^{\mathrm{a}}$ & $99.22^{\mathrm{a}}$ & $98.53^{\mathrm{b}}$ & $98.20^{\mathrm{ab}}$ & $97.18^{\mathrm{ab}}$ & $96.50^{\mathrm{b}}$ & $96.14^{\mathrm{b}}$ \\
\hline$(\mathrm{mg} / 100 \mathrm{~g})$ & \pm 5.32 & \pm 5.79 & \pm 5.48 & \pm 6.10 & \pm 6.98 & \pm 4.03 & \pm 4.50 \\
\hline Total flavonoids & $16.10^{\mathrm{a}}$ & $15.98^{\mathrm{a}}$ & $15.60^{\mathrm{ab}}$ & $15.31^{\mathrm{ab}}$ & $15.23^{\mathrm{ab}}$ & $14.90^{\mathrm{b}}$ & $14.58^{\mathrm{b}}$ \\
\hline$(\mathrm{mg} / 100 \mathrm{~g})$ & \pm 1.75 & \pm 1.99 & \pm 2.11 & \pm 2.28 & \pm 2.70 & \pm 2.52 & \pm 3.03 \\
\hline Total carotenoids & $174.98^{\mathrm{a}}$ & $174.07^{\mathrm{a}}$ & $173.80^{\mathrm{a}}$ & $173.54^{\mathrm{a}}$ & $173.22^{\mathrm{ab}}$ & $173.05^{\mathrm{b}}$ & $173.02^{\mathrm{b}}$ \\
\hline$(\mathrm{mg} / 100 \mathrm{~g})$ & \pm 11.43 & \pm 11.90 & \pm 12.11 & \pm 12.51 & \pm 12.90 & \pm 13.00 & \pm 13.12 \\
\hline L-Ascorbic acid & $280.25^{\mathrm{a}}$ & $276.42^{\mathrm{ab}}$ & $274.35^{\mathrm{ab}}$ & $271.29^{\mathrm{ab}}$ & $268.32^{\mathrm{b}}$ & $264.90^{\mathrm{c}}$ & $260.34^{\mathrm{d}}$ \\
\hline (Vitamin C-mg/100g) & \pm 16.52 & \pm 17.04 & \pm 17.88 & \pm 18.16 & \pm 18.92 & \pm 19.15 & \pm 20.98 \\
\hline Anthocyanins & $9.55^{\mathrm{a}}$ & $9.32^{\mathrm{a}}$ & $9.18^{\mathrm{ab}}$ & $9.13^{\mathrm{ab}}$ & $9.01^{\mathrm{ab}}$ & $8.70^{\mathrm{b}}$ & $8.50^{\mathrm{b}}$ \\
\hline$(\mathrm{mg} / \mathrm{g})$ & \pm 0.45 & \pm 0.69 & \pm 0.78 & \pm 0.95 & \pm 1.00 & \pm 1.11 & \pm 1.32 \\
\hline Antioxidant activity & $71.82^{\mathrm{a}}$ & $71.30^{\mathrm{a}}$ & $71.01^{\mathrm{a}}$ & $69.32 \mathrm{ab}$ & $68.93^{\mathrm{ab}}$ & $67.31^{\mathrm{b}}$ & $66.99^{\mathrm{b}}$ \\
\hline DPPH $(\%)$ & \pm 2.55 & \pm 2.93 & \pm 3.10 & \pm 4.00 & \pm 4.58 & \pm 4.98 & \pm 5.32 \\
\hline
\end{tabular}

${ }^{*}$ Moisture (\%) in fresh flesh: $81.94 \pm 2.35,{ }^{* *}$ Moisture (\%) in osmotic flesh (sucrose $40{ }^{\circ}$ Brix) $57.84 \pm 2.53$ (Water loss $24.6 \%)$

TSS ( ${ }^{\circ}$ Brix) in fresh flesh $16.50 \pm 1.03 \quad$ TSS ( ${ }^{\circ}$ Brix) in osmotic flesh (sucrose $40{ }^{\circ}$ Brix) $24.55 \pm 1.24$

Means having the same letter within raw are not significantly different at $\mathrm{p}<0.05$. Data were means \pm SD.

Results in table (6) contained changes of quality parameters and antioxidants activity in flesh lychee in sugar solution treatment during storage for 12 months in refrigerator $\left(4 \pm 1^{\circ} \mathrm{C}\right)$. Results indicated that the TSS, pH and acidity were ranged from 16.50, 4.42 and 0.38 to 15.95, 4.36 and 0.45 , respectively. In parallel, the content of total polyphenols, total flavonoids and total carotenoids were not significant changes during storage for 12 months. Vitamin $\mathrm{C}$ is found to be a major component in lychee, therefore vitamin $\mathrm{C}$ content in lychee in sugar solution was decrease $1.46 \%$ in after storage for 12 months and this decrement is not statistical significance. Also, it's observed that no significant change in anthocyanin contents during storage Antioxidant. The stability of antioxidant activity during storage may due to the decrement changes of antioxidant components are not significant, it's ranged from 81.78 to $78.10 \%$. So, 
it can store fresh lychee flesh in osmotic sucrose solution $\left(20^{\circ}\right.$ Brix) during for 12 months in refrigerator at $4 \pm 1^{\circ} \mathrm{C}$.

Results in table (7) showed the effect of osmotic oven air dried on osmotic flesh lychee in sucrose solution $\left(40^{\circ}\right.$ Brix) during storage for 12 months at room temperature. Total phenols, flavonoids, carotenoids and anthocyanins contents were not significantly decrease changes before 8 months. While, osmotic lychee vitamin $\mathrm{C}$ affected by oven dry treatment after 6 months, furthermore, vitamin $\mathrm{C}$ was decrease significant after 12 months was $7.10 \%$. Anyway, antioxidant activity in osmotic dehydrated lychee in oven dryer was significant decreased within storage for 10 and 12 months at ambient temperature. Generally, lychee in sucrose solution dried in oven dryer can be store till 8 months at ambient temperature.

Table 8. Effect of osmotic oven dried under vacuum $50^{\circ} \mathrm{C}$ (Osmovac) on flesh lychee during storage for 12 months at ambient temperature $\left(25 \pm 2^{\circ} \mathrm{C}\right)$.

\begin{tabular}{cccccccc}
\hline Constituents & 0-time & 2 months & 4 months & $\mathbf{6}$ months & $\mathbf{8}$ months & 10 months & 12 months \\
\hline Total polyphenols & $116.50^{\mathrm{a}}$ & $116.48^{\mathrm{a}}$ & $115.48^{\mathrm{a}}$ & $114.87^{\mathrm{a}}$ & $113.90^{\mathrm{ab}}$ & $112.40^{\mathrm{ab}}$ & $109.98^{\mathrm{b}}$ \\
& \pm 3.29 & \pm 4.25 & \pm 5.60 & \pm 6.11 & \pm 6.98 & \pm 7.22 & \pm 8.23 \\
Total flavonoids & $17.52^{\mathrm{a}}$ & $17.35^{\mathrm{a}}$ & $17.31^{\mathrm{a}}$ & $17.22^{\mathrm{a}}$ & $17.19^{\mathrm{a}}$ & $17.17^{\mathrm{a}}$ & $17.15^{\mathrm{a}}$ \\
& \pm 0.98 & \pm 1.14 & \pm 1.33 & \pm 1.28 & \pm 1.42 & \pm 1.50 & \pm 1.48 \\
Total carotenoids & $211.75^{\mathrm{a}}$ & $210.31^{\mathrm{a}}$ & $209.23^{\mathrm{a}}$ & $207.95^{\mathrm{ab}}$ & $207.21^{\mathrm{ab}}$ & $207.00^{\mathrm{ab}}$ & $201.26^{\mathrm{b}}$ \\
& \pm 7.25 & \pm 5.43 & \pm 6.28 & \pm 5.90 & \pm 7.22 & \pm 9.23 & \pm 12.54 \\
L-Ascorbic acid & $360.38^{\mathrm{a}}$ & $360.02^{\mathrm{a}}$ & $357.32^{\mathrm{ab}}$ & $356.10^{\mathrm{ab}}$ & $354.73^{\mathrm{ab}}$ & $350.98^{\mathrm{b}}$ & $350.00^{\mathrm{b}}$ \\
(Vitamin C) & \pm 10.53 & \pm 11.00 & \pm 15.32 & \pm 14.80 & \pm 15.75 & \pm 18.72 & \pm 19.50 \\
Anthocyanins & $11.46^{\mathrm{a}}$ & $11.20^{\mathrm{a}}$ & $11.08^{\mathrm{a}}$ & $10.99^{\mathrm{a}}$ & $10.87^{\mathrm{a}}$ & $10.27^{\mathrm{ab}}$ & $10.02^{\mathrm{b}}$ \\
(mg/g) & \pm 0.98 & \pm 1.22 & \pm 1.31 & \pm 1.27 & \pm 1.40 & \pm 1.25 & \pm 2.32 \\
Antioxidant activity & $78.32^{\mathrm{a}}$ & $78.20^{\mathrm{a}}$ & $78.01^{\mathrm{a}}$ & $77.83^{\mathrm{a}}$ & $77.49^{\mathrm{a}}$ & $76.99^{\mathrm{a}}$ & $75.84^{\mathrm{a}}$ \\
DPPH (\%) & \pm 4.92 & \pm 4.51 & \pm 5.43 & \pm 5.00 & \pm 4.91 & \pm 5.45 & \pm 5.32 \\
\hline
\end{tabular}

*Moisture (\%) in fresh flesh: $81.94 \pm 2.35,{ }^{* *}$ Moisture (\%) in osmotic flesh (sucrose $40{ }^{\circ}$ Brix) $57.84 \pm 2.53$ (Water $\operatorname{loss} 24.6 \%)$

TSS ( ${ }^{\circ}$ Brix) in fresh flesh $16.50 \pm 1.03 \quad$ TSS in osmotic flesh (sucrose $40{ }^{\circ}$ Brix) $24.55 \pm 1.24$

Means having the same letter within row are not significantly different at $\mathrm{p}<0.05$. Data were means \pm SD.

Polyphenols, carotenoids, anthocyanins contents had no significant decrease till 10 months (table 8). While, results showed no significant change in flavonoids content during storage period compared to dry oven treatment. But, the content of vitamin $\mathrm{C}$ was gradually significant decrease (from 360.38 to 350.00 $\mathrm{mg} / 100 \mathrm{~g})$, the percentage of decrement of vitamin $\mathrm{C}$ was $2.88 \%$ during storage period. While, the antioxidant activity will not be significantly affected during storage period.

Results in this table complied with [15] who decided that, vacuum drying was a suitable technique for producing shelf-stable litchi fruit with good texture while preserving its desirable original nutrients. Also, they added that Consumption of vacuum dried litchi may be beneficial to health due to its remarkable content of phenolic compounds and vitamin C. whose result suggests a shelf-life of eight months at $23{ }^{\circ} \mathrm{C}$.

\section{Conclusion}

Osmotic fresh and Osmovac dried lychee flesh fruits are very suitable in storage as their antioxidant contents can retain their high quality for (12 months) at room temperature compared to osmotic air dried flesh lychee fruits ( 8 months). While, seeds and pericarps rich in bioactive components may use in food and pharmaceutical products in further study. Therefore, it is recommended to use all parts of lychee fruits (flesh, seeds and pericarps) because its rich in vitamin $\mathrm{C}$ and antioxidants also, osmotic treatments is one of the best and suitable method to increase the shelf life of either fresh or dried lychee fruits. 


\section{References}

1. Yadva A.K. and Singh S.V. 2014. Osmotic dehydration of fruits and vegetables: A review. J. Food Sci. Technol., 51(9):1654-1673. DOI 10.1007/s13197-012-0659-2.

2. Tiwari R.B. 2005. Application of osmo-air dehydration for processing of tropical fruits in rural areas. Indian Food Ind., 24(6):62-69.

3. Wei Y.Z., Hu F.C., Hu G.B., Li X.J., Huang X.M. and Wang H.C. 2011. Differential expression of anthocyanin biosynthetic genes in relation to anthocyanin accumulation in the pericarp of Litchi chinensis Sonn. PLoS One 6:e19455.

4. Cabral T.A., Cardoso L.M. and Pinheiro-Sant Ana H.M. 2014. Chemical composition, vitamins and minerals of a new cultivar of lychee (Litchi chinensis cv. Tailandes) grown in Brazil. Fruits, 69 (6): 425-434.

5. Srivastava V., Viswakarma B., Deep P., Awasthi H., Verma S., Vishnoi R. and Verma S.K. (2018). A Phytopharmacological Review of Litchi chinensis. Int. J. Pharm. Sci. Rev. Res., 51(1): 58-65.

6. Singh J.P., Chandel R., Mishra B. and Suneetha V. 2013. Evaluation of antimicrobial and antioxidant property of lychee's seed for therapeutic purpose. Int. J. Pharm. Sci. Rev. Res., 19: 72-76.

7. Queiroz E.R., Patto de Abreu C.M., Oliveira K.S., Ramos V.O. and Fráguas R.M. 2015. Bioactive phytochemicals and antioxidant activity in fresh and dried lychee fractions. Rev. Ciênc. Agron., 46 (1): 163-169.

8. Wu Z.C., Yang Z.Y., Li J.G., Chen H.B., Huang X.M. and Wang H.C. 2016. Methyl-inositol, Y-aminobutyric acid and other health benefit compounds in the aril of litchi. Int. J. Food Sci. Nutr., 67:762-772.

9. Chyau C.C., Ko P.T., Chang C.H. and Mau J.L. 2003. Free and glycosidically bound aroma compounds in lychee (Litchi chinensis Sonn.). Food Chem., 80:387-392.

10. Wang H.C., Hu Z.Q., Wang Y., Chen H.B. and Huang X.M. 2011. Phenolic compounds and the antioxidant activities in litchi pericarp: difference among cultivars. Sci. Horti., 129:784-789.

11. Jiang G., Lin S. and Wen L. 2013. Identification of a novel phenolic compound in litchi (Litchi chinensis Sonn.) pericarp and bioactivity evaluation. Food Chem., 136:563-568.

12. Rustan A.C. and Drevon C.A. 2005. Fatty acids: Structures and Properties. Encyclopedia of Life Sciences, John Wiley \& Sons, Ltd. www.els.net.

13. CAC 2017. Report of the thirty-eighth session of the Codex Committee on nutrition and foods for special dietary uses. Fortieth Session CICG, Geneva, Switzerland, 17 - 22 July 2017.

14. Jiang Y.M., Zhu X.R. and Li Y.B. 2001. Postharvest control of litchi fruit rot by Bacillus subtilis. Food Science and Technology, 34:430-436.

15. Reis R.F., de Oliveira A.C., Gadelha G.G., de Abreu M.B. and Soares H.I. 2017. Vacuum drying for extending Litchi shelf-life: Vitamin C, total phenolics, texture and shelf-life assessment. Plant Foods Human Nutr., 72(2):120-125. doi: 10.1007/s11130-017-0602-9.

16. Akbarian M., Ghasemkhani N. and Moayedi F. 2013. Osmotic dehydration of fruits in food industrial: A review. Inter. J. Biosciences, 3(12): 1-16.

17. Tchango-Tchango J., Tailliez R., Eb P., Njine T. and Horenz J.P. 1997. Heat resistance of the spoilage yeasts Candida pelliculosa and Kloeckera apis and pasteurization values for some tropical fruit juices and nectars. Food Microbiol., 14(1): 93-99.

18. A.O.A.C. 2012. Official Methods of Analysis Association of Official Analytical Chemists International, $19^{\text {th }}$ Ed., Maryland, USA.

19. Mathew J.T., Ndamitso M.M., Otori A.A., Shaba E.Y. and Adamu A. 2014. Proximate and mineral compositions of seeds and some conventional and non-conventional fruits in Niger State. Nigeria Acad. Res. Int., 5(2): 113-118.

20. James, C.S. 1995. General Food Studies. In: Analytical Chemistry of Foods, Blachie Academic and Professional, London, New York, Tokyo, Chapter 6, 135.

21. Boligon A.A., Pereira R.P., Feltrin A.C., Machado M.M., Janovik V., Rocha J.B.T. and Athayde M.L. 2009. Antioxidant activities of flavonol derivates from the leaves and stem bark of Scutia buxifolia Reiss. Bioresour. Technol., 100: 6592-6598.

22. Pharmacopeia 1989. USSR, Moscow, Medicina, 2: 324-33 (in Russian).

23. Nagata M. and Yamashita I. 1992. Simple method for simultaneous determination of chlorophyll and carotenoids in tomato fruit. Nippon Shokuhin Kogyo Gakkaish, 39(10): 925-928.

24. Klein B.P. and Perry A.K. 1982. Ascorbic acid and vitamin A activity in selected vegetables from different geographical areas of the United States. J. Food Sci., 47: 941-945. 
25. Wrolstad R.E., Durst R.W. and Lee J. 2005. Tracking color and pigment changes in anthocyanin products. Trends Food Sci.Technol., 16: 423-428.

26. ISO Method (12966-2) 2011. Animal and vegetables fats and oil preparation of methyl esters of fatty acids.

27. Shimada K., Fujikawa K., Yahara K. and Nakamura T. 1992. Antioxidative properties of xanthan on the autioxidation of soybean oil in cyclodextrin emulsion. J. Agric. Food. Chem., 40: 945- 948.

28. SPSS 2000. Statistical package for Social Sciences. SPSS for windows version 19, SPSS Inc., Chicago, IL, USA.

29. FAO/WHO 2001. Human vitamin and mineral requirements. Chapter 7, P. 73-81. 